\title{
EFEKTIVITAS PERANAN LEMBAGA BANTUAN HUKUM TERHADAP PENANGANAN PERMASALAHAN PHK TENAGA KERJA DI PROVINSI BALI
}

\author{
Ni Ketut Elly Sutrisni(1), Charles Mouw ${ }^{(2)}$, \\ ellysutrisni@undiknas.ac.id ${ }^{(1)}$, charlie221095@gmail.com ${ }^{(2)}$
}

Fakultas Hukum dan IImu Sosial Undiknas

\begin{abstract}
The Legal Aid Foundation (YLBHI) Foundation of $L B H$ Bali noted that at least in 2017 there were 9 cases that were advocated and 3 of them were dismissal cases, namely layoffs at Sky Garden, Saba Villa and PT ESC Urban Food Station. The lawsuit filed by the plaintiffs or workers is related to workers' rights that have not been fulfilled by the company, namely severance pay, tenure award money, compensation for rights and unpaid wages or process wages, so it is necessary to review the effectiveness of the role of aid agencies law on handling the problem of layoffs of workers in Bali Province. This study uses an empirical juridical method by conducting interviews with informants and respondents. The effectiveness of the role of $\angle B H$ Bali's YLBHI and other LBHs in implementing the Law on Legal Aid is very influential in handling labor issues in Bali both litigation and nonlitigation. considering the needs of workers / laborers to access justice in order to fulfill their rights as workers / laborers.
\end{abstract}

Keywords: Legal Aid Institutions, Termination of Employment, Labor

\section{ABSTRAK}

Yayasan Lembaga Bantuan Hukum (YLBHI) LBH Bali mencatat setidaknya sepanjang tahun 2017 terdapat 9 kasus yang diadvokasi dan 3 kasus diantaranya adalah kasus PHK yakni kasus PHK di Sky Garden, Saba Villa dan PT ESC Urban Food Station. Gugatan yang diajukan oleh para penggugat atau pekerja adalah terkait dengan hak-hak pekerja yang belum dipenuhi oleh perusahaan yakni, uang pesangon, uang penghargaan masa kerja, uang penggantian hak dan upah yang belum dibayar atau upah proses, sehingga diperlukan penelahaan terhadap efektivitas peranan lembaga bantuan hukum terhadap penanganan permasalahan PHK tenaga kerja di Provinsi Bali. Penelitian ini menggunakan metode yuridis empiris dengan melakukan wawancara terhadap informan dan responden. Efektivitas peran YLBHI LBH Bali dan LBH lainnya dalam menjalankan UU bantuan Hukum sangatlah berpengaruh terhadap penanganan masalah ketenagakerjaan di Bali baik secara litigasi maupun non litigasi. mengingat kebutuhan para pekerja/ buruh untuk mengakses keadilan dalam rangka terpenuhinya hak-hak mereka sebagai pekerja/ buruh.

Kata Kunci: Lembaga Bantuan Hukum, Pemutusan Hubungan Kerja, Tenaga Kerja. 


\section{PENDAHULUAN}

Masalah ketenagakerjaaan merupakan masalah yang sangat rumit, karena masalah ini menyangkut masalah yuridis, sosiologis dan beragam bentuk lainnya, seperti jumlah lapangan pekerjaan yang terbatas, upah yang murah, jaminan keselamatan kerja dan perselisihan pemutusan hubungan kerja dan lain-lain sebagainya, oleh karena itu persoalan tenaga kerja adalah persoalan yang harus ditangani secara sungguh-sungguh. Disamping itu situasi menjadi bertambah buruk dengan terjadinya penyimpangan penerapan hukum yang terjadi dimana-mana yang berakhir dengan keberpihakan hukum kepada kelompok yang kuat dan berjouis termasuk para pemilik perusahaan, serta hukum dijadikan alat untuk menindas kelompok masyarakat yang lemah dan miskin. ${ }^{1}$

Pemutusan Hubungan Kerja (selanjutnya disebut PHK), merupakan salah satu masalah utama dalam ruang lingkup tenaga kerja, karena tenaga kerja atau buruh di Indonesia masih diperlakukan secara tidak adil baik oleh perusahaan maupun dalam proses penegakan hukum ketika terjadinya PHK sehingga kemudian muncul pertanyaan terhadap penegakan hukum di Indonesia untuk memberikan rasa keadilan bagi semua masyarakat Indonesia khususnya kaum buruh, karena sebagai negara demokrasi yang berlandaskan hukum dan negara hukum yang demokratis maka nilai-nilai penegakan hukum yang berkeadilan wajib di implementasikan dalam kehidupan berbangsa dan bernegara.

Meninjau permasalahan ketenagakerjaan di Provinsi Bali, maka berdasarkan data dari Dinas Tenaga Kerja dan Energi Sumber Daya Mineral Provinsi Bali (selanjutnya disebut Disnaker dan ESDM), terhitung dari Januari 2016 sampai pada Juli 2017 Terdapat 46 perusahaan yang bermasalah terkait dengan urusan tenaga kerja dan sebagian perusahaan tersebut bergerak dalam industri pariwisata, serta kemudian tercatat 44 karyawan di PHK. 250 karyawan bermasalah dengan BPJS kesehatan dan perselisihan hak. Kasus-kasus tersebut diselesaikan dengan melalui jalur litigasi yakni melalui Pengadilan Hubungan Industrial (selanjutnya disebut $\mathrm{PHI}$ ), serta dengan

${ }^{1}$ Bambang Waluyo, 2016, Penegakan Hukum DI Indonesia, Sinar Grafika, Jakarta, h. 32. 
diadakannya perjanjian bersama lewat mediasi yang dilakukan oleh para pihak yang bermasalah.

Yayasan Lembaga Bantuan Hukum (YLBHI) LBH Bali mencatat setidaknya sepanjang tahun 2017 terdapat 9 kasus yang diadvokasi dan 3 kasus diantaranya adalah kasus PHK yakni kasus PHK di Sky Garden, Saba Villa dan PT ESC Urban Food Station. Gugatan yang diajukan oleh para penggugat atau pekerja adalah terkait dengan hak-hak pekerja yang belum dipenuhi oleh perusahaan yakni, uang pesangon, uang penghargaan masa kerja, uang penggantian hak dan upah yang belum dibayar atau upah proses. Kasus-kasus PHK tersebut semuanya diselesaikan sesuai dengan ketentuan-ketentuan didalam UndangUndang Nomor 2 Tahun 2004 tentang Penyelesaian Perselisihan Hubungan Industrial (selanjutnya disebut UU PPHI), yang didalamnya terdapat tata cara penyelesaian mulai dari tahapan perundingan bipartit, tahapan mediasi atau konsiliasi dan tahapan terakhir yaitu gugatan melalui pengadilan hubungan industrial. ${ }^{2}$

Melihat permasalahan tersebut, maka sudah menjadi sebuah kebutuhan yang bersifat mendesak untuk menjamin keadilan dalam penegakan hukum untuk dapat terwujudsehingga kemudian muncul terebosandalam upaya untuk menciptakan keadilan bagi semua masyarakat yakni dengan diterbitkannya Undang-Undang Nomor 16 Tahun 2011 tentang Bantuan Hukum (selanjutnya disebut UU Bantuan Hukum) yang menghendaki adanya lembaga bantuan hukum dalam upaya untuk membela masyarakat miskin dan lemah termasukpara buruh yang di PHK untuk memperoleh hak-haknya serta diperlakukan adil dimata hukum. ${ }^{3}$

YLBHI LBH Bali sebagai salah lembaga non pemerintah yang bergerak memberikan bantuan hukum secara cuma-cuma kepada penerima bantuan hukum sebagaimana yang telah diamanatkan didalam UU Bantuan Hukum, melihat adanya keterkaitan yang sangat erat antara peraturan perundangan-undangan yang berlaku, kebijakan

2 Pujiyo, Ugo, 2011, Hukum Acara Penyelesaian Perselisihan Hubungan Industrial, Sinar Grafika, Jakarta, h. 53.

3 Yayasan Lembaga Bantuan Hukum Indonesia (YLBHI), Verboden Voor Honden EnInlandesrs (Catatan 40 Tahun Pasang Surut Keadilan), Institut studi Arus Informasi, Jakarta, h. 5. 
perusahaan dan penegakan hukum dengan masalah-masalah yang dihadapi oleh para pekerja di Bali, dimana para pekerja sering mengalami perlakuan yang menyimpang oleh perusahaan namun mereka cenderung tidak berdaya untuk membela dirinya dan hak-hak yang dimilki dikarenakan kurangnya peranan negara lewat pemerintah dan penegak hukum dalam membantu para pekerja yang bermasalah dengan PHK.

Berdasarkan uraian diatas, maka adapun rumusan masalah dalam penelitian ini adalah: Bagaimanakah efektivitas peranan lembaga bantuan hukum terhadap penanganan permasalahan PHK tenaga kerja di Provinsi Bali ?

\section{PEMBAHASAN}

\section{Efektivitas Peranan Lembaga Bantuan Hukum Terhadap Penanganan} Permasalahan PHK Tenaga Kerja di Provinsi Bali

Keberadaan Undang-Undang Nomor 16 Tahun 2018 tentang Bantuan Hukum, telah mengamanatkan terselenggaranya program bantuan hukum di Indonesia sekaligus memberikan legitimasi terbentuknya Lembaga Bantuan Hukum untuk menjalankan program bantuan secara cuma-cuma kepada masyarakat miskin dan termarjinalkan telah mencerminkan suatu pengimplementasian dari dari Pasal 1 Ayat (3) Undang-Undang Dasar Negara Republik Indonesia tahun 1945, yang menyatakan bahwa :

"Negara Indonesia adalah negara hukum"

Ketentuan konstitusi tersebut pada prinsipnya menegaskan keharusan bagi Indonesia untuk menyelenggarakan atau memberikan bantuan hukum kepada masyarakat miskin dan termarjinalkan sebagai konsekuensi dari status Indonesia sebagai Negara hukum yang demokratis.

Penyelenggaraan program bantuan hukum oleh LBH pada prinsipnya hanya di berikan kepada kelompok masyarakat yang dikategorikan sebagai masyarakat miskin yang tidak dapat memenuhi hak dasar secara layak dan mandiri, sebagaimana yang diatur didalam Pasal 5 ayat (1) UU Bantuan Hukum. Mencermati ketentuan tersebut maka pada prinsipnya kelompok buruh/ pekerja juga masuk dalam 
kategori masyarakat yang harus mendapat perhatian dalam penyelenggaraan program bantuan hukum oleh LBH tidak terkecuali para tenaga kerja di Bali. Efektif atau tidaknyanya suatu aturan hukum di pengaruhi oleh ketaatan terhadap hukum itu sendiri sehingga dengan demikian maka kedudukan lembaga bantuan menjadi penentu utama efektif atau tidaknya UU Bantuan Hukum, disisi lain masyarakat miskin yang berstatus sebagai penerima bantuan hukum juga dituntut untuk dapat menggunakan jasa bantuan hokum dengan baik dan sesuai dengan ketentuan-ketentuan dalam UU Bantuan Hukum.

Menurut Soerjono Soekanto, bahwa efektif atau tidaknya suatu hukum ditentukan oleh 5 (lima) faktor, yaitu ${ }^{4}$ :

a. Faktor hukumnya sendiri (undang-undang).

b. Faktor penegak hukum, yakni pihak-pihak yang membentuk maupun menerapkan hukum.

c. Faktor sarana atau fasilitas yang mendukung penegakan hukum.

d. Faktor masyarakat, yakni lingkungan dimana hukum tersebut berlaku atau diterapkan.

e. Faktor kebudayaan, yakni sebagai hasil karya, cipta dan rasa yang didasarkan pada karsa manusia di dalam pergaulan hidup.

Kedudukan lembaga bantuan menjadi penentu utama efektif atau tidaknya UU Bantuan Hukum, disisi lain masyarakat miskin yang berstatus sebagai penerima bantuan hukum juga dituntut untuk dapat menggunakan jasa bantuan hukum dengan baik dan sesuai dengan ketentuan-ketentuan dalam UU Bantuan Hukum.

Yayasan Lembaga Bantuan Hukum (YLBHI) LBH Bali mencatat setidaknya sepanjang tahun 2017 terdapat 9 kasus yang diadvokasi dan 3 kasus diantaranya adalah kasus PHK yakni kasus PHK di Sky Garden, Saba Villa dan PT ESC Urban Food Station. Gugatan yang diajukan oleh para penggugat atau pekerja adalah terkait dengan hakhak pekerja yang belum dipenuhi oleh perusahaan yakni, uang pesangon, uang penghargaan masa kerja, uang penggantian hak dan

${ }^{4}$ Sarjono Soekanto, 2008,Faktor-Faktor Yang Mempengaruhi Penegakan Hukum, PT . Raja Grafindo Persada, Jakarta, h. 8. 
upah yang belum dibayar atau upah proses.

Kepala Divisi Perburuhan YLBHI LBH Bali, Haerul Umam menyampaikan bahwa jumlah kasus yang ditangani saat ini tidaklah sebanyak kasus-kasus yang tidak terdeteksi atau tidak di advokasi oleh YLBHI LBH Bali mengingat keterbatasan YLBHI LBH Bali untuk menjangkau semuanya dan disisi lain kurangnya kesadaran dan pengetahuan pekerja terhadap hak-haknya sehingga semakin sulit untuk menjangkau banyak kasus PHK sepihak yang terjadi di Bali. ${ }^{5}$

Terdapat hal yang menarik dari data yang penulis peroleh dari Dinas Tenaga Kerja Provinsi Bali yakni pada tahun 2017 Jumlah perusahaan yang terdaftar di Disnaker Bali sebanyak 8.153, sedangkan jumlah pengawas yang ada di Provinsi Bali sebanyak 24 orang, tentu jumlah ini sangat tidak ideal dan pasti tidak akan maksimal dalam melakukan pengawasan. Bandingkan saja 1 orang pengawas harus mengawasi sebanyak 339 perusahaan, maka tidak heran jika banyak pelanggaran yang dilakukan oleh perusahaan dan minim sanksi dari pemerintah.

Selain itu sepanjang tahun 2016 - 2017, tidak ada perusahaan yang mengajukan penangguhan upah. Artinya sebanyak 8.153 perusahaan dianggap mampu untuk membayar upah sesuai dengan upah yang sudah ditentukan oleh Pemerintah Provinsi dan Pemerintah Kabupaten/Kota yang biasa disebut dengan Upah Minimum Provinsi (UMP) dan Upah Minimum Kabupaten/ Kota (UMK). Kemudian menurut Haerul Umam, pada prakteknya masih saja ada buruh yang menerima upah dibawah UMK, meskipun hal ini telah diatur dalam Undangundang No 13 Tahun 2003 tentang Ketenagakerjaan pasal 90 ayat (1) disebutkan bahwa

"Pengusaha dilarang membayar upah lebih rendah dari upah minimum sebagaimana dimaksud dalam Pasal 89", dan diatur pula ancaman pidananya pada pasal 185 (1) disebutkan bahwa "Barang siapa melanggar ketentuan sebagaimana dimaksud dalam Pasal 42 ayat (1) dan ayat (2), Pasal 68, Pasal 69 ayat (2), Pasal 80, Pasal 82, Pasal 90 ayat (1), Pasal 143, dan Pasal 160 ayat (4) dan ayat (7),

${ }^{5}$ Hasil wawancara dengan Bapak Haerul Umam S.H, selaku Kepala Divisi Perburuhan YLBHI LBH Bali, pada tanggal 27 Juni 2018. 
dikenakan sanksi pidana penjara paling singkat 1 (satu) tahun dan paling lama 4 (empat) tahun dan/atau denda paling sedikit $R p$ 100.000.000,00 (seratus juta rupiah) dan paling banyak $R p$ 400.000.000,00 (empat ratus juta rupiah)."

Pada penerapannya masih saja ada buruh yang menerima upah dibawah UMK, dan yang menjadi pertanyaan besar adalah berapa banyak perusahaan yang diberikan sanksi oleh pemerintah sesuai dengan UU Ketenagakerjaan. Permasalahan upah tersebut menunjukan kesewenang-wenangan perusahaan dalam memperlakukan buruh/ pekerja termasuk dalam melakukan PHK secara sepihak. $^{6}$

Berdasarkan Data jumlah kasus yang masuk ke PHI sepanjang 2014-2016, terjadi peningkatan jumlah kasus dengan total kasus PHK sebanyak 41 kasus PHK dan jumlah tersebut lebih banyak dari kasuskasus lainnya yang masuk di PHI. Menururt Haerul Umam sekalipun jumlah kasus yang masuk ke PHI di dominasi oleh kasus PHK, Namun jika melihat kasus PHK secara komprehensif, masih banyak kasus PHK yang tidak masuk ke PHI. Menurutnya Ada beberapa faktor yang menyebabkan kasus tersebut tidak masuk ke PHI diantaranya; dilakukan penyelesaian secara bipartit (antara pengusaha dan buruh), dilakukan penyelesaian secara mediasi di Dinas Tenaga Kerja, dan terkadang buruh memilih tidak menempuh jalur penyelesaian baik bipartit, mediasi bahkan ke PHI. Artinya buruh yang yang di PHK membiarkan saja kasus yang dialaminya dan memilih untuk mencari pekerjaan lain. ${ }^{7}$

Berdasarkan hasil pengkajian terhadap kasus-kasus PHK yang ditangani oleh YLBHI LBH Bali, terdapat kesamaan atau hubungan obyek sengketa PHK antara satu kasus dengan kasus yang lainnya, yakni berkaitan dengan pelanggaran PHK sepihak oleh perusahaan sebagaimana diatur didadalam Pasal 164 ayat (3) yang berbunyi :

"Pengusaha dapat melakukan pemutusan hubungan kerja terhadap pekerja/ buruh karena perusahaan tutup, bukan karena mengalami

${ }^{6}$ Hasil wawancara dengan Bapak Haerul Umam S.H, selaku Kepala Divisi Perburuhan YLBHI LBH Bali, pada tanggal 27 Juni 2018.

${ }^{7}$ Hasil wawancara dengan Bapak Haerul Umam S.H, selaku Kepala Divisi Perburuhan YLBHI LBH Bali, pada tanggal 27 Juni 2018. 
kerugian 2 (dua) tahun berturut-turut atau bukan karena keadaan memaksa (force mejeur) tetapi perusahaan melakukan efisiensi, dengan ketentuan pekerja/ buruh berhak atas uang pesangon sebesar 2 (dua) kali masa kerja, ketentuan Pasal 156 ayat (2), uang penghargaan masa kerja 1 (satu) kali ketentuan Pasal 156 ayat (3) dan uang pergantian hak sesuai dengan ketentuan Psal 156 ayat (4).

Menurut M. Hasan, kasus PHK yang dialaminya sengaja dimanipulasi oleh pihak manajemen perusahaan dengan menciptakan situasi dimana dirinya dianggap didiskualifikasikan mengundurkan diri sebagaimana yang diatur didalam Pasal 168 ayat (1) UU Ketenagakerjaan. Berdasarkan hasil putusan PHI ditemukan fakta dalam persidangan bahwa saudara M. Hasan tidak melakukan tindakan yang melanggar ketentuan tersebut namun oleh pihak manajemen perusahaan dibuat seakan-akan saudara M. Hasan melanggar ketentuan tersebut. Menurut Haerul Umam hal tersebut seringkali dilakukan oleh pihak manajemen perusahaan, agar dibebaskan dari tanggung jawab mereka membayar uang pesangon dan lain-lainnya sebagaimana yang diatur didalam UU Ketenagakerjaan. ${ }^{8}$

Permasalahan PHK buruh/ pekerja di Bali, sesungguhnya merupakan konsekuensi dari status Bali sebagai salah satu kota industri parawisata terbesar di Indonesia dengan jumlah perusahaan yang mencapai 8.153 perusahaan sehingga di perlukan peran pemerintah dalam menjamin terselenggaranya kegiatan ketenagakerjaan yang kondusif dan berkeadilan bagi semua pihak baik pengusaha maupun tenaga kerja.

YLBHI LBH Bali sebagai lembaga penyalur bantuan hukum secara cuma-Cuma, sangatlah penting keberadaannya, karena berdasarkan pernyataan M. Hasan bahwa kelompok buruh/ pekerja seperti dirinya seringkali mengalami diskriminasi oleh perusahaan, namun disisi lain keterbatasan menggunakan jasa pengacara untuk membela dirinya membuat hak-haknya sebagai buruh/ pekerja sulit untuk di dapatkan, sehingga ketika ada LBH, maka para buruh dapat memiliki peluang untuk mendapatkan akses keadilan dengan cara menempuh jalur hukum baik

\footnotetext{
${ }^{8}$ Hasil wawancara dengan Bapak M. Hasan, selaku buruh/ pekerja di PT
} ESC Urban Food Station, pada tanggal 18 Juli 2018. 
secara litigasi maupun non litigasi. ${ }^{9}$

YLBHI LBH Bali dengan konsep bantuan hukum strukturalnya, berupaya mengimplementasikan nilai-nilai bantuan hukum sebagaimana yang diatur didalam Pasal 1 ayat (1) UU Bantuan Hukum yang berbunyi :

"bantuan hukum adalah jasa hukum yang diberikan oleh pemberi bantuan hukum secara cuma-cuma kepada penerima bantuan hukum"

Bantuan hukum struktural pada prinsipnya mengakomodasi dua bentuk penyeleksaian kasus atau perkara hukum yakni melalui litigasi dan non litigasi, karena disamping menyelesaikan perkara lewat proses peradilan, BHS juga menjalankan alternatif penyelesaian sengketa atau Alternative Dispute Resolution (ADR) yang terdiri dari konsultasi, negosiasi, mediasi, dan konsiliasi. Alternatif penyelesaian sengketa pada dasarnya merupakan bagaian yang paling penting dalam pengimplementasian BHS, karena salah satu aspek penting dari BHS adalah adanya pengorganisasian masyarakat untuk dapat secara mandiri membela dan mengupayakan pemenuhan hak-haknya.

Hal tersebut menjadikan BHS dan teori hukum progresif memiliki keterkaitan yang sangat erat, karena sama halnya dengan BHS, gagasan hukum progresif tidak semata-mata hanya memahami sistem hukum pada sifat yang dogmatik, selain itu juga aspek perilaku sosial pada sifat yang empirik. Sehingga keselarasan BHS dan teori hukum progresif yang di jalankan oleh YLBHI LBH Bali, diharapkan dapat melihat problem buruh / pekerja secara utuh, dalam menyajikan hukum yang berorientasi terhadap keadilan substantif bagi kelompok buruh/ pekerja di Bali. ${ }^{10}$

\section{PENUTUP}

\section{A. Kesimpulan}

Permasalahan Buruh di Bali, penulis berkesimpulan bahwa, dari tahun ke tahun kasus perburuhan di Bali jumlahnya semakin meningkat, terutama kasus Pemutusan Hubungan Kerja (PHK), dan ancaman PHK bisa menimpa siapa saja (buruh) tanpa mengenal

${ }^{9}$ Hasil wawancara dengan Bapak M. Hasan, selaku buruh/ pekerja di PT ESC Urban Food Station, pada tanggal 18 Juli 2018.

10 Julius Ibrani, 2013, Bantuan Hukum (Bukan Hak Yang Diberi), YLBHI, Jakarta, h. 163. 
dimana bekerja, apa pekerjaannya, dan siapa pengusahanya, baik aktif di Serikat Pekerja/Serikat Buruh atau tidak. Sehingga untuk menciptakan penyelenggaraan kegiatan ketenagakerjaan yang berkadilan bagi kaum buruh/ pekerja di Bali, sangat dibutuhkan keberadaan YLBHI LBH Bali untuk menjalankan secara komprehensif amanat UU bantuan Hukum.

\section{B. Saran}

adapun saran yang dapat penulis sampaikan adalah, bahwa dalam rangka menciptakan efektivitas peranan $\mathrm{LBH}$, perlu adanya upaya untuk mensosialisasikan UU Bantuan Hukum kepada masyarakat agar keberadaan LBH dapat di manfaatkan dengan sebaik-baiknya. serta mendorong pemerintah dalam hal ini Disnaker dan ESDM untuk menambah sumberdaya tenaga pengawasnya agar dapat menjawab kebutuhan pengawasan terhadap perusahaanperusahaan yang beroperasi di Bali sehingga kecendrungan pelanggaran hukum oleh perusahaan dapat diketahui dan di tindaklanjuti demi untuk menciptakan situasi yang berkeadilan bagi semua pihak khususnya buruh/ tenaga kerja di Bali

\section{DAFTAR PUSTAKA}

\section{Buku:}

Ibrani,Julius, 2013, Bantuan Hukum (Bukan Hak Yang Diberi), YLBHI, Jakarta.

Pujiyo, Ugo, , Hukum Acara Penyelesaian Perselisihan Hubungan Industrial, Sinar Grafika, Jakarta.

Soekanto,Sarjono, 2008,Faktor-Faktor Yang Mempengaruhi Penegakan Hukum, PT . Raja Grafindo Persada, Jakarta.

Waluyo,Bambang, 2016, Penegakan Hukum DI Indonesia, Sinar Grafika, Jakarta.

Yayasan Lembaga Bantuan Hukum Indonesia (YLBHI), Verboden Voor Honden EnInlandesrs (Catatan 40 Tahun Pasang Surut Keadilan), Institut studi Arus Informasi, Jakarta. 


\section{Peraturan Perundang-Undangan:}

Undang-Undang No 16 Tahun 2011 tentang Bantuan Hukum, Lembaran Negara Republik Indonesia Tahun 2011 Nomor 104 dan Tambahan Lembaran Negara Republik Indonesia Nomor 5248, mulai berlaku pada tanggal 2 November 2011.

Undang-Undang No. 13 tahun 2003 tentang Ketenagakerjaan, Lembaran Negara Republik Indonesia Tahun 2003 Nomor 39 dan Tambahan Lembaran Negara Republik Indonesia Nomor 4279, mulai berlaku pada tanggal 25 Maret 2003. 